\title{
DETERMINANT OF IMPLEMENTATION PROFIT SHARING FINANCING IN ISLAMIC BANKING
}

\author{
Winarsih*, Wanda Asokawati \\ * Corresponding author: \\ Faculty of Economics, Sultan Agung Islamic University \\ winarsih@unissula.ac.id.,asokawati.wanda@gmail.com
}

\begin{abstract}
One of the characteristics of Islamic banking is using the concept of profit sharing financing. This study aims to determinan of implementation profit sharing financing, consist of Third Party Funds, Non Performing Financing, Return On Assets, Capital Adequacy Ratio and Financing to Deposit Ratio. The population in this study are all Islamic banking which listed in Bank of Indonesia in the periode 2013 to 2016. The sample was selected using purposive sampling methodTotal samples used in this study were 11 Islamic Banks with 4-year study period, with get sampleof 44 data. The analytical method used in this study is multiple regression were processed using SPSS. The results of this study indicate third party funds, financing to deposit ratio have a positive significant effect to the financing profit sharing. While non performing financing, return on asset and capital adequacy ratio no effect on the profit sharing financing.
\end{abstract}

Keywords: Profit sharing financing, islamic banking

\section{INTRODUCTION}

Sharia bank is a bank that conducts its business activities based on the sharia principles from Qur'an, Hadist and ijmak from the scholars (Maradita, 2014), which consist of sharia Bank and the people's financing sharia bank. According to law No. 21 of 2008, Sharia banking is everything related to sharia banks and sharia business units, including institutional, business activities, ways and processes in conducting its business activities. As the Islamic Shariah outlined. Mumtazah and Septiarini (2016) stated that sharia banking was established because the increasing knowledge and understanding of public interest in conventional banking was categorized as interest ( $r i b a$ ) where it is haram. The characteristic of sharia banking system that operates based on revenue sharing principles provides an alternative banking system that is mutually beneficial for people and banks, and brings out the aspects of fairness in transacting, ethical investments, prioritize the values of togetherness and brotherhood in production, also avoid speculative activities of financial transactions. However, in practice, the implementation of revenue sharing of sharia banks has not optimal yet. It is because murabahah financing is more widely used in financing distribution so that the financing of murabahah still dominates financing contract. According to Arnan \& Kurniawasih (2014) although the revenue sharing becomesdifferentiator between sharia banks and conventional banks, the financing has not been able to dominate the highest financing in sharia banks. It is because the risk of moral hazard is high.

Sharia banks collect funds from various sources of funds, such as from third party funds in the form of demand deposit, saving, and time deposit. Thus, the high number of third party funds will influence the volume of funds that can be developed in the financing activities of sharia banks. It is in line with the research of Choirudin and Praptoyo (2017) mentioning that 
DPK (Deposito Mudharabah) influence Mudharabah financing.

Another aspect that may influence revenue share financing is the risk, where the risk of financing measured by Non Performing Financing (NPF) that use to measure the amount of financial risks faced by the distributed funds. Maryanah in Choirudin and Praptoyo (2017) stated that Non performing financing (NPF) is the financing percentage of problematic outcomes on overall financing. The need for financing loss allowance becomes high when the problem financing is also high, therefore the ratio of NPF can affect the low level of financing. Destiana (2016) shows that Mudharabah and Mutanaqisah financing are influenced by NPF, different with the research results of Umiyati and Ana (2017) suggested that NPF has no effect on financing.

The next factor that affects revenue share financing is Return On Asset (ROA). According to Forestiana (2014) the profitability ratio is required to be a benchmark of the extent of management capabilities in managing sharia banks to get benefit from their operational activities. The income gained from financing can be used to finance operational activities, so that revenues that exceed the cost of banking will gain profit and reflected through ROA. The larger ROA will cause the larger financing. The results of Farianto (2014) is that ROA as an independent variable (X1) affects the rate for Mudharabah (Y) deposits. Meanwhile the research by Wirawan (2016) suggested that ROA does not affect the level of mudharabah deposit results.

The fourth factor that can affect the revenue share financing is CAR, the ratio of the minimum capital fulfillment obligation that a bank must obtain. Thus, if a bank with large capital can distribute more financing. Choirudin and Praptoyo (2017) concluded that CAR affects Mudharabah financing. Meanwhile research from Reswanda and Revelation (2013) showed that CAR has an influence on financing.

There are various rules by Bank Indonesia on financing distribution, including rules regarding FDR. Muhamad (2016:193) stated that FDR ratio illustrates the level of liquidity owned by financial institution (Bank), which is the percentage of financing that has been made by the bank with the third party. If the ratio of the FDR to a bank is greater, it represents that the bank is low of liquidity capability.

According to Amriani in Reswanda and Wahyu (2013), FDR reflects the bank's performance in repaying withdrawals made by the depositors' with relying on the financing given as a source of liquidity. The research results of Umiyati and Ana (2017) stated that FDR affects financing. However, the research conducted by Forestiana (2014) showed a different outcome, which is a significant negative effect on Mudharabah financing.

\section{LITERATURE REVIEW}

\section{Agency Theory}

Agency theory according to Anthony and Govindarajan in Wirawan (2016) is defined as a theory which describes the relationship between principals and agents. The agency relationship in this case is not available when depositors entrust their money to be managed by the related BUS. On the basis that the management is obliged to provide accurate reporting and disclosure of financial statements related with BUS performance to the principal (depositor) as there will be differences in information received by the depositor and the BUS to informatuon 
asymmetry.

\section{The Influence of Third Party Fund towards Revenue Share}

Third party funds are public funds or funds gathered from society in the form of deposits. The presence of assets available in Sharia banks is positively related to the level of product financing distribution. Therefore, the more third party funds obtained from society, the higher financing based on revenue distributed to the society. Research conducted by Umiyati and Ana (2017) stated that third party funds has an effect on financing of BUSD in Indonesia.

$\mathrm{H}_{1}$ : Third party funds give positive effect towards revenue share financing

\section{The Influence of Non Performing Financing (NPF) towards Revenue Share Financing}

NPF is a ratio of financing that has problem with total financing distributed by banks. According to Pratama in Reswanda and Wahyu C (2013), NPF reflects credit risk, the smaller NPF, the smaller credit risk by the bank. The research conducted by Destiana (2016) stated that the risks measured with NPF have a positive effect on Mudharabah and Musyarakah financing. $\mathrm{H}_{2}$ : Non Performing Financing (NPF) give positive effect towards revenue share financing

\section{The Influence of Return On Asset (ROA) towards Revenue Share Financing}

Return On Asset (ROA) is one of the profitability ratios to measure the effectiveness of company in generating profits by leveraging its total assets it. Profit earned can be channeled for financing, so the increase in profits obtained by the bank will increase the volume of financing. The research conducted by Farianto (2014) stated that ROA has an effect on the outcome of Mudharabah.

$\mathrm{H}_{3}$ : Return On Asset (ROA) give positive effect towards revenue share financing

\section{The Effect of Capital Adequacy Ratio (CAR) towards Revenue Share Financing}

CAR is one of the bank solvency ratio that uses to see the bank's capital can support bank activities (fund channeling) efficiently. CAR is the capability of the bank's capital in enduring losses incurred as a result of the loss of financing. Thus, the more capital that the banker has, the more bank will be channeled. The opinion is supported by research conducted by Choirudin and Praptoyo (2017), stated that CAR has a positive effect on mudharabah financing.

$\mathrm{H}_{4}$ : Capital Adequacy Ratio (CAR) give positive effect towards revenue share financing

\section{The Effect of Financing to Deposit Ratio (FDR) towards Revenue Share Financing}

According to Muhammad in Trisnadi (2014), FDR ratio is used to measure the ability of Sharia banks in conducting a good intermediation function. The higher FDR ratio, the better bank in carrying out its intermediate function. This opinion is in line with the research conducted by Umiyati and Ana (2017) stated that FDR affects the financing of BUSD in Indonesia.

$\mathrm{H}_{5}$ : Financing to Deposit Ratio (FDR) give positive effect towards revenue share financing 


\section{RESEARCH METHOD}

\section{Variable Operational Definition and Variable Measurement}

1. Revenue Share Financing (Y)

According to Muhamad (2016:41) financing is funding given by a party to other parties to support the investment that has been planned, both personal and institution. In other words financing is funding issued to support planned investment.

Revenue share financing: Mudharabah financing + Musyarakah financing

\section{Third Party Funds}

From banking operations, third party fund is a source of liquidity to facilitate the financing on the asset side of the balance sheet. Third party funds comes from cheque, savings and deposits

Third party funding: cheques + savings + deposits

\section{Non Performing Financing (NPF)}

Arianti in Agista (2015) stated that the indicator which indicates the loss due to credit risk is reflected by the magnitude of non-performing loan (NPL), in the terminology of Sharia banks called non perfoming financing (NPF). NPF is ratio between problematic financing and total financing distributed by sharia banks.

\section{Financing to Deposit Ratio (FDR)}

Muhamad (2016:193) stated that financing to deposit ratio is a comparison of financing provided by banks with third party funds successfully compiled by banks. If a bank is high, it indicates that the bank is less liquid, so if the bank has a low FDR ratio it indicates that the bank is in a liquid state.

\section{Population and Sample}

The population in this research is registered sharia Banks in Bank Indonesia. The sampling techniques uses purposive sampling method. The following are the criteria of sampling:

\begin{tabular}{|c|l|c|}
\hline Number & Sample Criteria & Total \\
\hline 1 & Registered sharia bank in Bank Indonesia period of 2013-2016 & 12 \\
\hline 2 & $\begin{array}{l}\text { Sharia Banks which have complete financial data and provide a } \\
\text { report in rupiah per December 31 each year. }\end{array}$ & 12 \\
\hline 3 & $\begin{array}{l}\text { Sharia banks which inconsistent in reporting financial } \\
\text { statements during the year required in the research }\end{array}$ & 1 \\
\hline 4 & Total sample (N Data) ( 4 years x 11 sharia banks) & 44 \\
\hline 5 & Processed data (N) & 44 \\
\hline
\end{tabular}




\section{ANALYSIS TECHNIQUE}

\section{Descriptive Statistica; Analysis}

The descriptive statistical analysis will illustrate the maximum, minimum, standard deviation, and mean values of the variable data used in the research. Below are the results of descriptive statistical analysis:

Table 1

Descriptive Statistics
\begin{tabular}{|l|l|l|l|l|l|}
\hline \multicolumn{1}{|c|}{} & N & Minimum & Maximum & Mean & Std. Deviation \\
\hline DPK & 44 & 174 & 69950 & $1.59 E 4$ & 20230.293 \\
NPF & 44 & .00 & 7.00 & 2.9091 & 1.85294 \\
ROA & 44 & -3.00 & 3.00 & .4886 & 1.30066 \\
CAR & 44 & 11.00 & 36.00 & 18.7500 & 6.72768 \\
FDR & 44 & 79.00 & 120.00 & 93.2500 & 8.48288 \\
PBH & 44 & 39.00 & 21273.00 & $4.5935 \mathrm{E3}$ & 6193.02325 \\
Valid N (listwise) & 44 & & & & \\
\hline
\end{tabular}

\section{Classical Assumption Test}

This assumption test is used to determine whether the data to be used in this research already satisfies regression models or not. The classical assumption test is done by testing normality, heteroscedasticity test, multicolinearity test and autocorrelation test.

\section{Normality Test}

The aim of normality test is to test whether in regression model, the bully or residual variables have a normal distribution or not. This test uses the Kolmogrov Smirnov method. Below is a table of results from normality test Table 2

\begin{tabular}{|c|c|c|}
\hline & & Unstandardized Residual \\
\hline $\mathrm{N}$ & & 44 \\
\hline \multirow[t]{2}{*}{ Normal Parameters ${ }^{\mathrm{a}}$} & Mean & .0000000 \\
\hline & Std. Deviation & 3.38907149E3 \\
\hline \multirow[t]{3}{*}{ Most Extreme Differences } & Absolute & .124 \\
\hline & Positive & .124 \\
\hline & Negative & -.116 \\
\hline Kolmogorov-Smirnov Z & & .823 \\
\hline Asymp. Sig. (2-tailed) & & .507 \\
\hline
\end{tabular}

a. Test distribution is Normal.

\section{Normality Tes}

\section{One-Sample Kolmogorov-Smirnov Test}

Based on the results from the table above, it can be concluded that the significant value is $0.507>0.05$ or it can be concluded that the residual data has been distributed normally so that subsequent classical assumptions can be tested. 


\section{Autocorrelation Test}

Autocorrelation test is used to determine whether a correlation occurs between members of a sample sorted by time or not. A good regression model is a regression that is free of autocorrelation issues. In order to test whether autocorrelation is measured using Durbin Watson (DW) statistics. The Durbin-Watson test results can be seen in the following table:

\section{Tabel 3}

Autocorrelation Model Summary

\begin{tabular}{|l|l|l|l|l|l|}
\hline Model & $R$ & R Square & $\begin{array}{l}\text { Adjusted R } \\
\text { Square }\end{array}$ & $\begin{array}{l}\text { Std. Error of } \\
\text { the Estimate }\end{array}$ & Durbin-Watson \\
\hline 1 & $.837^{\mathrm{a}}$ & .701 & .661 & 3605.14851 & 2.138 \\
\hline
\end{tabular}

a. Predictors: (Constant), FDR, ROA, NPF, CAR,TPF

b. Dependent Variable:PBH

The autocorrelation test results by using Durbin-Watson test show a calculated D-W value of 2.138 for $\mathrm{N}=44$ and $\mathrm{k}=5$. These results are located between the values $\mathrm{d}_{\mathrm{U}}(1.7777)$ and $4-\mathrm{d}_{\mathrm{U}}(2.2223)$ so it can be concluded that this regression model is free of autocorrelation symptoms.

\section{Multicollinearity Test}

This test aims to test whether or not there is a strong relationship in data or correlation between independent variables. A good regression model is if there is no correlation in the data. If the value is VIF $<10$ and tolerance value tolerance $>0$. The following results from multicolinearity test:

Table 4

Multicolinearity Test

Coefficients ${ }^{\mathrm{a}}$
\begin{tabular}{|ll|l|l|}
\hline \multirow{2}{*}{$\begin{array}{l}\text { Model } \\
\text { Tolerance }\end{array}$} & \multicolumn{2}{|l|}{ Collinearity Statistics } \\
\cline { 2 - 4 } & VIF & \\
\hline 1 & DPK & .550 & 1.818 \\
& NPF & .598 & 1.673 \\
& ROA & .719 & 1.391 \\
& CAR & .669 & 1.496 \\
& FDR & .628 & 1.591 \\
\hline
\end{tabular}

a. Dependent Variable: $\mathrm{PBH}$

The results of table 4 indicate that VIF value is $<10$ and the tolerance value is $>0$. So, it can be concluded that in independent variables there is no strong or multicolinearity free relationship 


\section{Uji Heteroscedasticity}

Heteroscedasticity test aims to test whether or not in a regression model there is a variance inequality of residue/observation to other observations, it is called homocedasticity when it is different called heteroscedasticity. A good regression model is homosvedastisity, Ghozali (2011). The results of heteroscedasticity tests can be seen in the following table:

Table 5

Heterocedasticity Coefficients Test

\begin{tabular}{|c|c|c|c|c|c|}
\hline \multirow{2}{*}{$\begin{array}{l}\text { Model } \\
\text { B }\end{array}$} & \multicolumn{2}{|c|}{$\begin{array}{l}\text { Unstandardized } \\
\text { Coefficients }\end{array}$} & \multirow[t]{2}{*}{$\begin{array}{l}\text { Standardized } \\
\text { Coefficients }\end{array}$} & \multirow[t]{2}{*}{$\mathrm{t}$} & \multirow[t]{2}{*}{ Sig. } \\
\hline & Std. Error & Beta & & & \\
\hline 1 (Constant) & 11.522 & 4.912 & & 2.346 & .024 \\
\hline TPF & 4.467E-5 & .000 & .364 & 1.838 & .074 \\
\hline NPF & -.338 & .254 & -.253 & -1.329 & .192 \\
\hline ROA & -.104 & .331 & -.055 & -.315 & .755 \\
\hline CAR & -.104 & .066 & -.283 & -1.576 & .123 \\
\hline FDR & .054 & .054 & .185 & .997 & .325 \\
\hline
\end{tabular}

a. Dependent Variable

Referring to table 5, the results of heteroscedasticity test each with a TPF of 0.074 , NPF of 0.192 , ROA of 0.755 , CAR of 0.123 and FDR of 0325 , then it can be interpreted that the results of each data $>0.05$ so that the research data is free of heterosCesdaacity and deserves further analysis.

\section{Multiple Linear Regression Analysis}

A good multiple linear regression model is the one that fulfill the classic assumption test criteria. Based on previous test and analysis results it can be concluded that the model used in this study has fulfilled the criteria of classical assumptions, so that the model in the study is considered as the good one. The result of regression equation model is: 
Table 6

Model Persamaan Regresi Coefficients ${ }^{\mathrm{a}}$

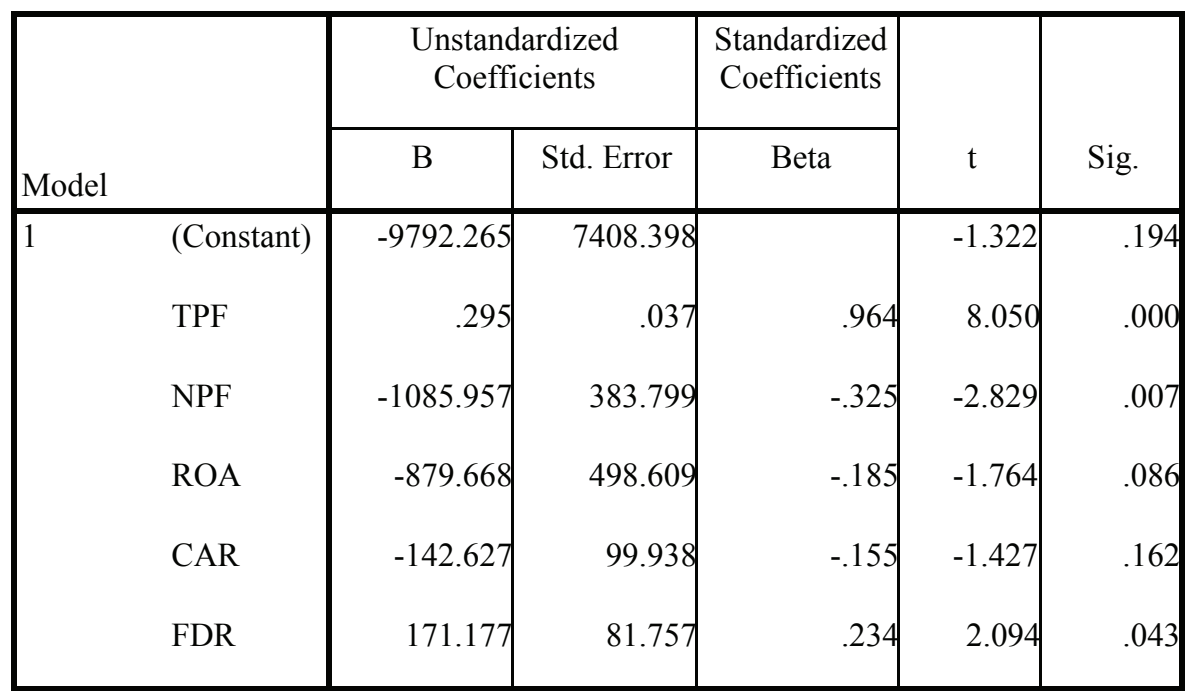

a. Dependent Variable: based on the table above, the result of processed data using IBM SPSS 16.0 can be obtained the regression equity model as follows:

$$
\begin{aligned}
\mathrm{Y}= & -9792.265+0.295 \mathrm{DPK}-1085.957 \mathrm{NPF}-879.668 \mathrm{RO}_{\mathrm{A}}- \\
& 142.627 \mathrm{CAR}+171.177 \mathrm{FDR}+\mathrm{e}
\end{aligned}
$$

\section{MODEL'S BENEFITS TEST}

\section{Significant Simultaneous Test (Uji F)}

The test of simultaneous influence is used to determine whether the variables independently or simultaneously affect the dependent variable, Ghozali 2013. The test criterion is if $\mathrm{F}$ count $>\mathrm{F}$ table then it means the variable is freely capable Explain the variables bonded together.

The following is a table of test results performed by $\mathrm{F}$ :

\begin{tabular}{|l|l|l|l|l|l|}
\hline Model & $\begin{array}{l}\text { Sum of } \\
\text { Squares }\end{array}$ & Df & $\begin{array}{l}\text { Mean } \\
\text { Square }\end{array}$ & F & Sig. \\
\hline $1 \quad$ Regression & $1.155 \mathrm{E} 9$ & 5 & $2.311 \mathrm{E} 8$ & 17.778 & $.000^{\mathrm{a}}$ \\
Residual & $4.939 \mathrm{E} 8$ & 38 & & & \\
Total & $1.649 \mathrm{E} 9$ & 43 & $1.300 \mathrm{E} 7$ & & \\
\hline
\end{tabular}

a. Predictors: (Constant), FDR, ROA, NPF, TPF,DPK

b. Dependent Variable:PBH

Based on the results of the provessed data it appears that the F-count value is 17,778 with a significant value of 0.000 . It means that the significant value is $<0.05$, thereby it can be concluded that free variable on the model is feasible. 


\section{Determination Coefficient Test}

Determination coefficient test is used to see the ability of independent variables in explaining the change variation of dependent variables. The coefficient of determination can be seen from the adjusted value of R2, where to interpret the magnitude value of the coefficient of determination should be changed in the form of percentages. The following is the table of test results:

Table 8

Determination Coefficient Test $\left(\mathrm{R}^{2}\right)$

Model Summary ${ }^{b}$

\begin{tabular}{|l|l|l|l|l|l|}
\hline Model & $R$ & R Square & $\begin{array}{l}\text { Adjusted R } \\
\text { Square }\end{array}$ & $\begin{array}{l}\text { Std. Errorof } \\
\text { theEstimate }\end{array}$ & Durbin-Watson \\
\hline 1 & $.837^{\mathrm{a}}$ & .701 & .661 & 3605.14851 & 2.138 \\
\hline
\end{tabular}

a. Predictors: (Constant), FDR, ROA, NPF, CAR, TPF

b. Dependent Variable:PBH

Table above obtained the adjusted value $\mathrm{R}^{2}$ for 0.661 . That result explains if the free variable in its entirety has almost all the required information that will be used as a predictor of the variation against the bound variable. The 0.661 or $66.1 \%$ of free variables affect the bound variables, while the remainder of 0.339 or $33.9 \%$ is influenced by other variables.

\section{Hypothesis Test (t-test )}

The hypothesis testing uses the t-test, which is to know the influence of each of the variables independent of the dependent variables (Ghozali, 2013). The following is the result of a t-test:

Tabel 9

Uji Hipotesis (Uji t)

Coefficients $^{\mathrm{a}}$

\begin{tabular}{|c|c|c|c|c|c|c|}
\hline \multirow{2}{*}{\multicolumn{2}{|c|}{$\begin{array}{l}\text { Model } \\
\text { B }\end{array}$}} & \multicolumn{2}{|c|}{$\begin{array}{l}\text { Unstandardized } \\
\text { Coefficients }\end{array}$} & \multirow{2}{*}{$\begin{array}{l}\text { Standardized } \\
\text { Coefficients }\end{array}$} & \multirow[b]{2}{*}{$\mathrm{T}$} & \multirow[b]{2}{*}{ Sig. } \\
\hline & & Std.Error & Beta & & & \\
\hline \multirow[t]{6}{*}{1} & (constant) & -9792.265 & 7408.398 & & -1.322 & .194 \\
\hline & DPK & .295 & .037 & .964 & 8.050 & .000 \\
\hline & NPF & -1085.957 & 383.799 & -.325 & -2.829 & .007 \\
\hline & ROA & -879.668 & 498.609 & -.185 & -1.764 & .086 \\
\hline & CAR & -142.627 & 99.938 & -.155 & -1.427 & .162 \\
\hline & FDR & 171.177 & 81.757 & .234 & 2.094 & .043 \\
\hline
\end{tabular}

a. Dependent Variable: PBH 


\section{RESEARCH RESULT AND DISCUSSION}

Based on the results of the t-test, it can be concluded the hypothesis result is as follows:

\begin{tabular}{|l|l|l|}
\hline Hypothesis & Significance & Hypothesis \\
\hline $\mathrm{H}_{1}:$ TPF give positibe effect towards revenue share financing & $0,000<0,05$ & Hypothesis $\quad 1$ \\
& t value 8.050 & Accepted \\
\hline $\mathrm{H}_{2}:$ NPF give positibe effect towards revenue share financing & $0,007<0,05$ & Hypothesis 2 \\
& t value -2.829 & rejecred \\
\hline $\mathrm{H}_{3}:$ ROA give positibe effect towards revenue share financing & $0,086>0,05$ & Hypothesis $\quad 3$ \\
& t value -1.764 & rejecred \\
\hline $\mathrm{H}_{4}:$ CAR give positibe effect towards revenue share financing & $0,162>0,05$ & Hypothesis \\
& t value -1.427 & rejecred \\
\hline $\mathrm{H}_{5}:$ FDR give positibe effect towards revenue share financing & $0,043<0,05$ & Hypothesis 5 \\
& t value 2.094 & Accepted \\
\hline
\end{tabular}

\section{DISCUSSION}

\section{Thirdh Party Funds towards Revenue Share}

Results of the research showed that TPF has a positive effect on financing for revenue share. The results of this research are in accordance with the research conducted by Pratami (2011), that TPF has significant effect on financing. Research with similar results is also done by Praptoyo (2017), namely Deposito Mudharabah has a positive influence over Mudharabah financing. Thus the hypothesis stated that TPF positively affects the financing of the revenue share received.

\section{Non Performing Financing (NPF) towards Revenue Share}

Based on the results of the research came it can be concluded that NPF negatively affects the financing of revenue share. The resultant research is in line with research conducted by Maesun et al (2016) which shows NPF negatively affect the financing of revenue share. Therefore, the hypothesis stated that NPF positively affects the revenue share financing is rejected.

\section{Return On Asset (ROA) towards Revenue Share}

Based on the research it can be concluded that ROA negatively affects the financing of revenue share. The higher ROA, it will result in the declining financing of revenue share. The results of this research are supported by the research results that have been done by Wirawan (2016) where ROA negatively affects the financing for revenue share in Sharia banks. Thus the hypothesis stated that ROA positively affects the financing of revenue share is rejected. 


\section{Capital Adequacy Ratio (CAR) towards Revenue Share}

The results showed that CAR has negative effect on financing for revenue share. It means that CAR is increasing, it makes the revenue share more declining. The results of this research are supported by the research results of Reswanda and Wenda Wahyu C (2016) which proved that CAR negatively affects financing. However, the hypothesis that says CAR positively affects the financing of the reveue share is rejected.

\section{Financing to Deposit Ratio (FDR) towards Revenue Share}

Referring to the research that has been done, it can be known that FDR gibes positive effect on revenue share financing. The results of this research are in line with the research result conducted by Umiyati and Ana (2017) which stated that FDR affects financing on BUS in Indonesia. Thus the hypothesis that states FDR has positive effect on revenue share financing is received.

\section{CONCLUSION}

According to results of the test. that have been done and discussed, then it can be concluded that TPF gives positive effect towards revenue share, NPF gives negative effect towards revenue share, ROA gives negative effect towards revenue share, CAR gives negative effect towards revenue share and FDR gives positive effect towards revenue share. However there are limitations in this research, such as sharia banks mostly choose negative ROA and the research object is only limited on BUS. Therefore, the rurther research should extend the observation period because in this research is limited only in the year 2013-2016, and can add objects in research such as UUS and sharia financing banks registered By diBI. It also recommended for further researchers to add variables such as interest rates, government policies, inflation or exchange rates.

\section{REFERENCES}

Annisa, L.N., and R. Yaya. 2015. Pengaruh Dana Pihak Ketiga (DPK), Tingkat Bagi Hasil dan Non-Performing Financing (NPF) Terhadap Volume dan Porsi Pembiayaan Berbasis Bagi Hasil Pada Perbankan Syariah. Jurnal Volume dan Porsi Pembiayaan : Volume 4 Number1.

Choirudin, A., and S. Praptoyo. 2017. Analisis Faktor yang Mempengaruhi Pembiayaan Bagi Hasil Mudharabah Pada Bank Umum Syariah. Jurnal Ilmu dan Riset Akuntansi : Volume 6 Nomor 9 ISSN : 2460-0585.

Destiana, R. 2016. Analisis Dana Pihak Ketiga dan Risiko Terhadap Pembiayaan Mudharabah dan Musyarakah Pada Bank Syariah di Indonesia. Jurnal Logika : Volume XVII No. 2 ISSN :1978-2560.

Farianto, A. 2014. Analisis Pengaruh Return On Asset (ROA), BOPO dan Bi- Rate Terhadap Tingkat Bagi Hasil Deposito Mudharabah Pada Bank Umum Syariah Di Indonesia Tahun 2012-2013. Equilibrium : Vol 2 No1. 
Ghozali, Imam. 2013. Aplikasi Analisis Multivariate Dengan programSPSS. Semarang : Badan Penerbit Universitas Diponegoro.

Haqqi, H. 2016. Analisis Pengaruh Non Performing Financing (NPF), Financing To Deposit Ratio (FDR), Inflasi dan Capital Adequacy Ratio (CAR) Terhadap Porsi Pembiayaan Murabahah Pada Bank Umum Syariah di Indonesia. Skripsi. Universitas Muhamadiyah Surakarta, Surakarta.

Irmawati, E.D. 2014. Pengaruh FDR, Pembiayaan Jual Beli, Pembiayaan Bagi Hasil, Pembiayaan Sewa Menyewa, Dan NPF Terhadap Profitabilitas (Studi Pada Bank Umum Syariah di Indonesia Periode Tahun 2009-2013).

Skripsi. Universitas Diponegoro, Semarang.

Katmas, E. 2014.Pengaruh Faktor Eksternal dan Internal Terhadap Volume Pembiayaan Perbankan Syariah di Indonesia.Skripsi. UIN Syarif Hidayatullah, Jakarta.

Liliani dan Khairunnisa. 2015. Pengaruh Dana Pihak Ketiga (DPK), Non Performing Financing (NPF), dan Capital Adequacy Ratio (CAR) Terhadap Pembiayaan Bagi Hasil Pada Bank Umum Syariah di Indonesia Periode 2010-2013. Jurnal e-proceeding Of Management : Vol 2 No 3 ISSN : 2355-9357.

Muhamad. 2016. Manajemen Pembiayaan Bank Syari'ah. Yogyakarta: UPP STIMYKPN.

Muliawati, S., and M. Khoiruddin. 2015. Faktor-Faktor Penentu Profitabilitas Bank Syariah di Indonesia. Management Analysis Journal ISSN : 2252- 6552.

Mumtazah, W., and D.F. Septiarini.2016. Analisis Faktor-Faktor yang Mempengaruhi Jumlah Dana Pihak Ketiga Pada Bank Umum Syariah di Indonesia (Periode Triwulan I 2010-Triwulan I 2015).

Peraturan Bank Indonesia Nomor: 7/46/PBI/2005

Peraturan Bank Indonesia Nomor 10/15/PBI/2008

Reswanda and A. Wahyu C. 2013. Pengaruh Dana Pihak Ketiga, Capital Adequacy Ratio, Financing To Deposits Ratio, dan Non Performing Financing Terhadap Penyaluran Pembiayaan Pada PT BPRS Lantabur Jombang .ISSN :1412-5366.

SE BI No.9/24/Dpbs/2007 SE BI No 13/24/DPNP/2011

Trisnadi. 2014. Pengaruh Financing To Deposits Ratio (FDR) dan Dana Pihak Ketiga (DPK) Terhadap Pembiayaan Mudharabah (Studi Kasus Pada Bank Umum Syariah Yang Terdaftar di Bank Indonesia Tahun 2012-2014).

Umiyati and L.T. Ana. 2017. Faktor-Faktor yang Mempengaruhi Pembiayaan Pada Bank Umum Syariah Devisa di Indonesia. Jurnal Ekonomi dan Perbankan Syariah : Vol 5 No 1 ISSN (cet) :2355-1755.

UU No. 21 Tahun 2008

Wirawan, A. 2016. Pengaruh ROA, ROE, BOPO, Terhadap Tingkat Bagi Hasil Deposito Mudharabah Pada Bank Umum Syariah. Artikel Ilmiah. STIE Perbanas, Surabaya. 
Yanti, I. 2014. Pengaruh Rasio Return Profit Loss Sharing Dibanding Return Total Pembiayaan, Bi-Rate, dan Kurs Terhadap Non Performing Financing (NPF) pada Bank Umum Syariah Milik Negara di Indonesia.Skripsi. UIN Sultan Syarif Kasim,Riau.

Yurmaini. 2011. Faktor-Faktor yang Mempengaruhi Akad Bagi Hasil Pada PT Bank Muamalat Indonesia Tbk. Tesis. IAIN Sumatera Utara, Medan. 